\title{
GROUND LIQUEFACTION AND DEFORMATION ANALYSIS OF BREAKWATER STRUCTURES UNDER EARTHQUAKES
}

\author{
Jie Zhao \\ Yumei Wang \\ Gaojie Yun \\ Muhammad Aqeel Ashraf \\ Civil Engineering Technology Research and Development Center, Dalian University, Dalian, 116622, \\ China \\ Faculty of Science and Natural Resources, University Malaysia Sabah 88400 Kota Kinabalu Sabah, \\ Malaysia
}

\begin{abstract}
Ground liquefaction and deformation is one of the important causes that damage engineering structures. Chinese current code for seismic design of breakwater is based on the single-level seismic design method as well as code for port and water-way engineering. However, this code can not exactly reflect the seismic performance of breakwater structures which experience different seismic intensities. In this paper, the author used a finite difference software, namely, FLAC3D, to analyze the state and compute seismic responses of breakwater structure. The breakwater foundation's pore pressure ratio and displacement due to different earthquake have been studied. And the result show that: Smaller earthquakes have little influence on serviceability of the foundation, and severe earthquakes can liquefy some parts of the foundation; In the latter case, obvious changes of pores and foundation displaces can be found. Particularly, when seismic peak acceleration reachs $0.2 \mathrm{~g}$, Liquefaction appears in the foundation and mainly concentrated in the upper right side of the structure. In addition, the survey of ultra-hole pressure and displacement values of sand layers of the breakwater, manifests when the ultra pore pressure near 1.0, displacement and overturning structure is relatively large, resulting in varying degrees of damage to the structure. This paper's research can provide theoretical and designable reference for similar engineering structures
\end{abstract}

Keywords: Breakwater, seismic design, liquefaction, excessive pore pressure ratio, displacement

\section{INTRODUCTION}

Breakwater port construction has the widespread application in our country, so it has strict requirements for its bearing capacity, suitable for rock and soil, sand and dense clay geological conditions. Since the 1970s, there have been several large earthquakes around the world, many dikes and buildings suffered extensive damages [1]. Liquefaction and ground deformation are the main characteristics of earthquake damage to the breakwater, so breakwater structure for liquefaction and deformation analysis is an important research content of the seismic design. Liquefaction experienced a series of research and development, H.B.Seed, who first proposed the free liquefaction simplified identification method [2]; Fang Yun et al. [3] analyzes the deformation mechanism under conditions of seismic liquefaction gravity pier design suggestions proposed seismic stability of gravity wharf; Ma Shuo [4] describes the damage types of Japan's Kobe earthquake in harbor pier, river embankment and disaster situation, analyze the reasons for failure, earthquake disaster prevention recommendations proposed wharf, embankment; Wang Li-yan et al. [5] The indirect liquefaction of a single index characterizing breakwater up residual deformation from the physical nature of the relationship between the breakwater obtain function prediction residual deformation and liquefaction degrees. Zhao Jie [12] using effective stress dynamic analysis methods, to obtain a stable ground motion a nuclear diversion dike full coefficient, distribution and post-earthquake liquefaction zone residual deformation. Liu Hanlong et al. [13] In multiple shear 
strain space plasticity model for the constitutive relationship of agency landside dock reasonably easy to handle liquefied soil foundation gives advice. Xu Zhiying et al [14] in accordance with the principle of effective stress analysis method is proposed to calculate the two-dimensional dynamic seismic response of saturated soil, considering not only the dynamic shear strain and dynamic non-linear relationship between shear modulus, but also take into account the dynamic pore water pressure gradually effects of growth and change in the nature of power. Ren Jingang et al [15] analyzed the mechanism of liquefaction of saturated sand and sand liquefaction judgment visualization methods.

At present, Chinese water transport project about the breakwater earthquake resistance design, primarily designed [6] in accordance with the relevant provisions of the foundation and the seismic slope, but confined to the limits of the force balance [7]. Fewer domestic and foreign scholars have studied the problem on the liquefaction of the foundation about the breakwater structure [16-18]. In this paper, the finite difference software FLAC3D reclamation project of a large breakwater revetment structure numerical simulation, analysis of the breakwater structure under different seismic pore pressure ratio and changes in the deformation, summed liquefaction and deformation law in breakwater structure and provided theoretical and design reference for similar engineering structures.

\section{NUMERICAL ANALYSIS PRINCIPLES OF FLAC3D}

\section{DYNAMIC PORE PRESSURE MODELS}

FLAC3D can simulate sand hole in the dynamic action of the pressure accumulation until soil liquefaction, using Finn model to describe the effect of the accumulation of pore water pressure, the essence of the model is to increase the dynamic pore water pressure rises mode based on Moore Coulomb model, and assume dynamic pore water pressure rises with plastic volumetric strain increments on [8].

Located in the sand when the effective stress $\sigma_{0}{ }^{\prime}$ onedimensional modulus of resilience is $E_{r}$, then the relationship under untrained pore pressure increment $\Delta u$ and $\Delta \varepsilon_{v d}$ plastic volumetric strain increments are as follows:

$$
\Delta u=\bar{E}_{r} \Delta \varepsilon_{v d}
$$

Byrne [9] uses the experimental data of Martin and Seed, proposed a more simple method of calculation about plastic volumetric strain increment:

$$
\Delta \varepsilon_{v d}=\gamma C_{1} \exp \left(-C_{2} \frac{\varepsilon_{v d}}{\gamma}\right)
$$

Where: $\gamma$ is the first $\mathrm{N}$ cycles shear strain amplitude; $\varepsilon_{v d}$ is the cumulative volume strain; $C_{1}, C_{2}$ of $D_{r}$ and sand relative density and correction standard penetration hammering parameters related to the number of $N_{1}$, is calculated as follows:
$C_{2}=\frac{0.4}{C_{1}}, C_{1}=7600\left(D_{r}\right)^{-2.5} \quad C_{1}=8.7\left(N_{1}\right)_{60}{ }^{-2.5}, \quad D_{r}=15\left(N_{1}\right)^{1 / 2}{ }_{60}$

\section{LIQUEFACTION STANDARD}

In the numerical calculation using the concept of excess pore pressure ratio to describe liquefaction, excess pore pressure ratio represented by $r_{u}=1-\frac{\sigma_{m}}{\prime}, \sigma_{m 0}^{\prime}$ driven before calculating the average effective stress $\sigma_{m q i t}, \sigma_{m}^{\prime}$ is dynamic calculation process mean effective stress. Theoretically, when the excess pore pressure of 1:00, sand liquefaction, but a large number of experimental data indicate that excess pore pressure has not reached 1:00, sandy soil liquefaction phenomenon occurs [7].

\section{DYNAMIC BOUNDARY CONDITIONS}

After the process of absorption of seismic reflection seismic waves on the boundary of the calculation model set free field boundary, set the free-field boundary, FLAC3D program will automatically form a free-field around the model grid mesh through the body and free-field Grid earthquake simulation coupling to approximate free field response [7]. Damping in the form of the use of local dampers, which through the node or node structures to increase or decrease the quality of the way to achieve convergence of the vibration cycle, due to the increased quality and reduced unit cell mass are equal, so that the system is to maintain the quality of conservation, the damping is taken as: 0.314 .

\section{SEISMIC ANALYSIS BREAKWATER STRUCTURES}

\section{DYNAMIC ANALYSIS MODEL}

A large land reclamation breakwater structure shown in Figure, the model length $60 \mathrm{~m}$, high $50 \mathrm{~m}, 20 \mathrm{~m}$ thickness direction of the foundation model, the model is partly sand,
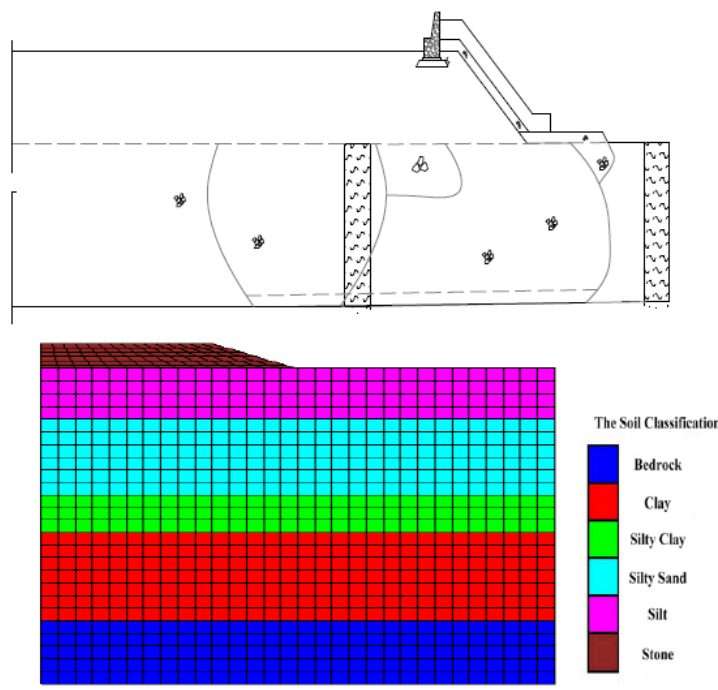

Fig.1 Breakwater structure cross plan and grid model (unit: $m$ ) 
and a large area, as well as the superstructure $4 \mathrm{~m}$ high filling section, above the water line is assumed part. Breakwater foundation profiles and meshes structure shown in Figure 1, geotechnical parameters used in calculation of fluid parameters and liquefaction parameters in Table 1, 2.

Tab.1 Geomechanical parameters and fluid and liquefaction parameters for soil liquefaction analysis

\begin{tabular}{|c|c|c|c|c|c|c|}
\hline 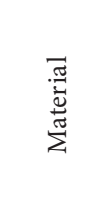 & 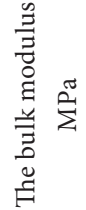 & 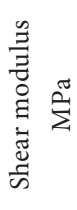 & 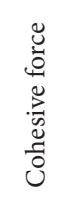 & 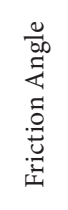 & 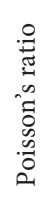 & 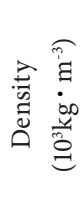 \\
\hline Silt & 7.9 & 2.1 & 10.0 & 10.6 & 0.3 & 1.57 \\
\hline $\begin{array}{l}\text { Silty } \\
\text { Sand }\end{array}$ & 68.6 & 26.3 & 0.00 & 35.0 & 0.3 & 1.94 \\
\hline $\begin{array}{l}\text { Silty } \\
\text { clay }\end{array}$ & 16.4 & 5.5 & 13.0 & 14.7 & 0.3 & 1.97 \\
\hline Clay & 173.7 & 5.8 & 16.0 & 16.0 & 0.3 & 1.84 \\
\hline Bedrock & 1250.0 & 576.9 & 0.0 & 30.0 & 0.3 & 2.04 \\
\hline Stone & 147.1 & 56.4 & 0.0 & 36.0 & 0.3 & 1.80 \\
\hline
\end{tabular}

Tab 2: Fluid and liquefaction parameters for soil liquefaction analysis

\begin{tabular}{|c|c|c|c|c|}
\hline Material & Porosity & 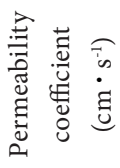 & $\begin{array}{l}\text { Damping } \\
\text { ratio }\end{array}$ & $\begin{array}{l}\text { Liquefaction } \\
\text { parameters }\end{array}$ \\
\hline Silt & 0.45 & $1.00 \mathrm{E}-11$ & 0.314 & - \\
\hline Silty Sand & 0.45 & $1.00 \mathrm{E}-09$ & 0.314 & $\begin{array}{c}C_{1}=1.2 C_{2}=0.79 \\
D_{r}=0.25\end{array}$ \\
\hline Silty clay & 0.45 & $1.00 \mathrm{E}-12$ & 0.314 & - \\
\hline Clay & 0.45 & $1.00 \mathrm{E}-12$ & 0.314 & - \\
\hline Bedrock & 0.45 & $1.00 \mathrm{E}-15$ & 0.314 & - \\
\hline Stone & - & - & 0.314 & - \\
\hline
\end{tabular}

Assuming the peak horizontal acceleration as $0.1 \mathrm{~g}, 0.15 \mathrm{~g}$, $0.2 \mathrm{~g}$ of EI-Centro seismic loading, to give its dynamic analysis models by 8400 units, 9922 nodes, breakwater foundation dynamic analysis model structure shown in Figure 2.

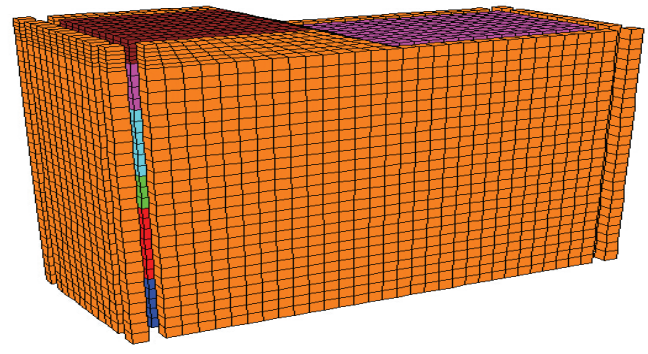

Fig.2 Dynamic analysis model

\section{SEISMIC INPUT}

Our water transport engineering seismic design code (JTS 146-2012) [6] using return period of 475 years (50 years beyond the design basis of the probability of 10\%) of the design earthquake, according to building codes considered equivalent fortification earthquake, and only seismic design force from extreme balance, are single-level design; Our reference herein seismic design of buildings (GB500112010) [10] regarding the multiple earthquake, fortification earthquake and rare earthquake action time history analysis peak ground acceleration of the relevant provisions of the breakwater structure foundation were time-history analysis, using American EI-Centro seismic waves, seismic waves duration 30s. Figures 3 and 4 are EI-Centro earthquake wave graph and the Fourier spectrum of the curve, it can be seen, seismic wave spectral components more complex, mainly concentrated on the less frequency $5 \mathrm{~Hz}$.

The specific dynamic analysis and calculation, bedrock ground motion acceleration input consider three cases, $0.10 \mathrm{~g}$, $0.15 \mathrm{~g}$ and $0.20 \mathrm{~g}$, respectively 7 degree earthquake, 7.5 degree earthquake and 8 degree earthquake.

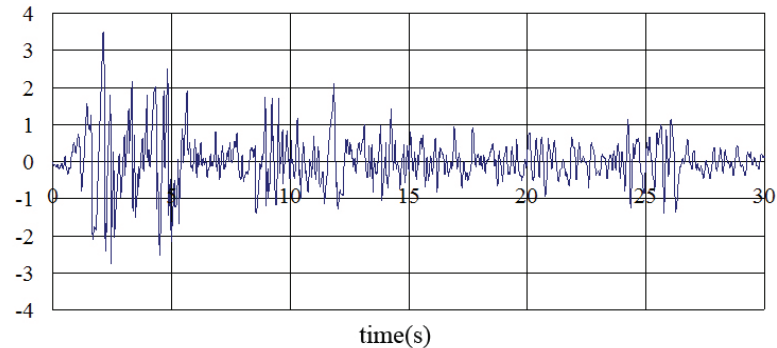

Fig.3 EI-Centro earthquake curve

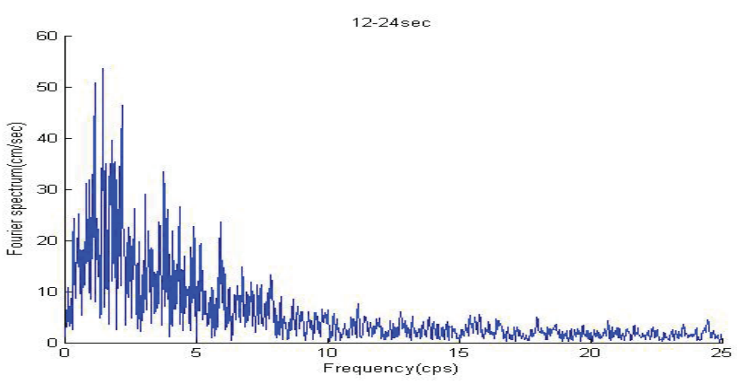

Fig.4 Fourier curve

\section{BREAKWATER LIQUEFACTION AND DEFORMATION ANALYSIS}

\section{LIQUEFACTION ANALYSIS UNDER DIFFERENT EARTHQUAKE}

In order to determine liquefaction foundation breakwater structure, the calculation of excess pore pressure ratio structure foundation sand layer numerically monitor, Figure 5 shows the position of $\mathrm{A}, \mathrm{B}, \mathrm{C}, \mathrm{D}$ four monitoring points, obtained in 0.1 under $\mathrm{g}, 0.15 \mathrm{~g}$ and $0.2 \mathrm{~g}$ peak acceleration, excess pore 
pressure at the location of the sand layer is not the same as the ratio of the distribution, over time $0.1 \mathrm{~g}$ pore pressure ratio in the range of 0.4 to 0.8 ; when $0.15 \mathrm{~g}$ excess pore pressure ratio in the range of $0.45-0.94 ; 0.2 \mathrm{~g}$ when the excess pore pressure ratio of $0.59-1$. According to a large number of experimental data that excess pore pressure ratio does not meet the 1:00 also be judged as liquefaction, according to research data [7], this paper take excess pore pressure ratio of 0.7 when it is determined that liquefaction.

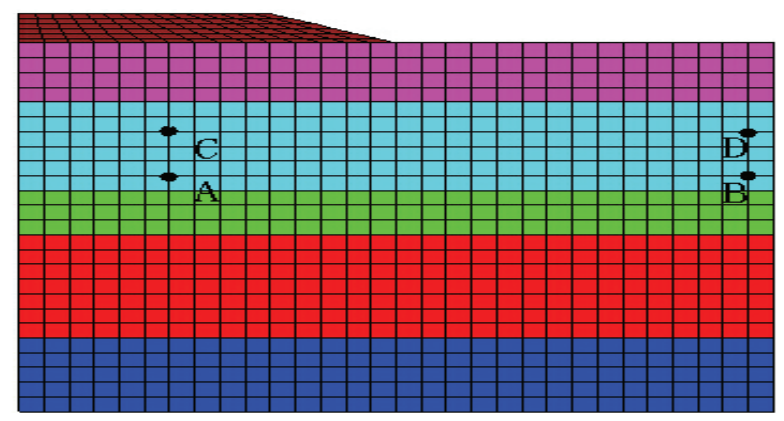

Fig.5 A, B, C, D four monitoring points' position

Tab 3:Different peak acceleration of monitoring points pore pressure ratio

\begin{tabular}{|c|c|c|c|c|}
\hline $\begin{array}{l}\text { Monitoring } \\
\text { stations } \\
\text { Peak } \\
\text { acceleration }\end{array}$ & A & B & C & D \\
\hline $0.10 \mathrm{~g}$ & 0.41 & 0.62 & 0.62 & 0.83 \\
\hline $0.15 \mathrm{~g}$ & 0.45 & 0.68 & 0.60 & 0.94 \\
\hline $0.20 \mathrm{~g}$ & 0.59 & 0.74 & 0.86 & 1.00 \\
\hline
\end{tabular}
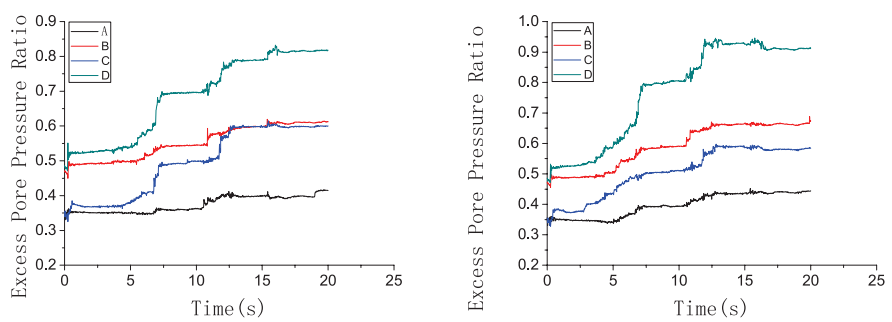
$0.1 \mathrm{~g}$
$0.15 \mathrm{~g}$

\section{BREAKWATER CONSTRUCTION GROUND DEFORMATION ANALYSIS}

Table 4 shows the horizontal and vertical directions at different representative monitoring point earthquake residual deformation size, it can be seen, when the peak acceleration is $0.10 \mathrm{~g}$, the deformation in the horizontal direction is $0.21-0.24 \mathrm{~m}$, vertical displacement as $0.06-0.08 \mathrm{~m}$; when peak acceleration is $0.15 \mathrm{~g}$, the deformation in the horizontal direction is 0.23 $0.26 \mathrm{~m}$, the vertical displacement is $0.06-0.08 \mathrm{~m}$; when peak acceleration $0.20 \mathrm{~g}$, the deformation in the horizontal direction

Fig 6 Different acceleration peak under A, B, C, D of excess pore pressure ratio curve
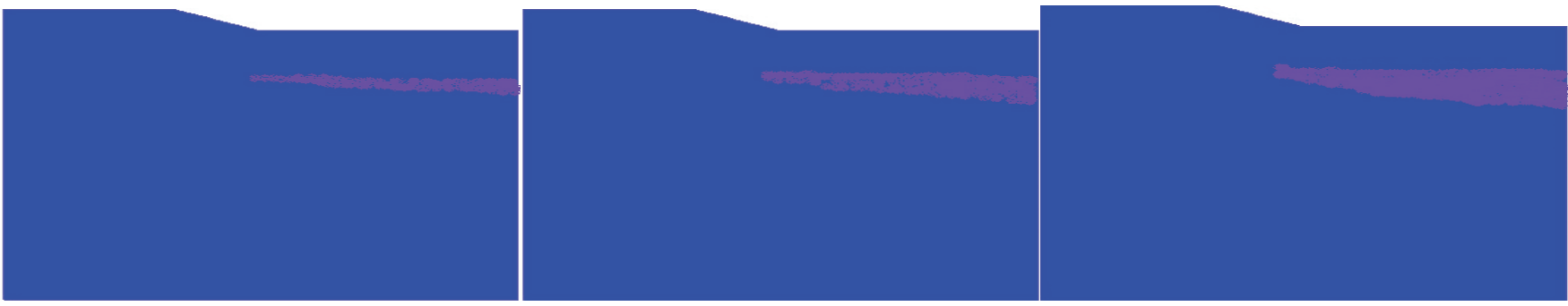

Fig 7:Different acceleration peak liquefaction area 
is $0.24 \mathrm{~m}-0.30 \mathrm{~m}$, vertical displacement of $0.07 \mathrm{~m}-0.09 \mathrm{~m}$.

Tab 4: Monitoring points horizontal and vertical displacement (unit: $m$ )

\begin{tabular}{|c|c|c|c|c|c|c|c|c|}
\hline \multirow[b]{2}{*}{$\begin{array}{l}\text { Peak } \\
\text { acceleration }\end{array}$} & \multicolumn{2}{|c|}{ A } & \multicolumn{2}{|c|}{ B } & \multicolumn{2}{|c|}{ C } & \multicolumn{2}{|c|}{ D } \\
\hline & 『 & : & 总 & : & $\overline{\vec{D}}$ & 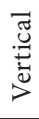 & 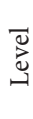 & \\
\hline $0.10 \mathrm{~g}$ & స̦ & $\begin{array}{l}0 \\
0 \\
0 \\
0\end{array}$ & กี & 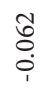 & $\stackrel{H}{J}$ & $\begin{array}{l}\text { ô } \\
\stackrel{0}{0} \\
0\end{array}$ & 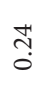 & \\
\hline $0.15 \mathrm{~g}$ & 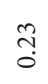 & $\begin{array}{l}0 \\
0 \\
0 \\
0\end{array}$ & กิ & $\begin{array}{l}\text { ช. } \\
0 \\
0\end{array}$ & $\stackrel{\text { In }}{\text { in }}$ & $\begin{array}{l}m \\
\infty \\
0 \\
0\end{array}$ & $\stackrel{2}{0}$ & \\
\hline $0.20 \mathrm{~g}$ & $\stackrel{\text { N }}{\text { ஸे }}$ & $\begin{array}{l}\stackrel{0}{\infty} \\
\stackrel{0}{0}\end{array}$ & $\stackrel{+}{\stackrel{H}{0}}$ & $\begin{array}{l}\infty \\
: \\
0 \\
0\end{array}$ & 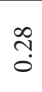 & $\begin{array}{l}\infty \\
\stackrel{0}{0} \\
0\end{array}$ & กั & \\
\hline
\end{tabular}

Three different earthquake, horizontal deformation of $0.2 \mathrm{~m}$ $0.3 \mathrm{~m}$ or so, in the same direction with the original model, but the vertical direction appeared deformed in both directions, if the middle part of the junction will appear on the left side a variation of tilt, and the right side of the liquefied area that is larger deformation occurs in the form of sinking, namely the breakwater structure appeared overturning deformation form.
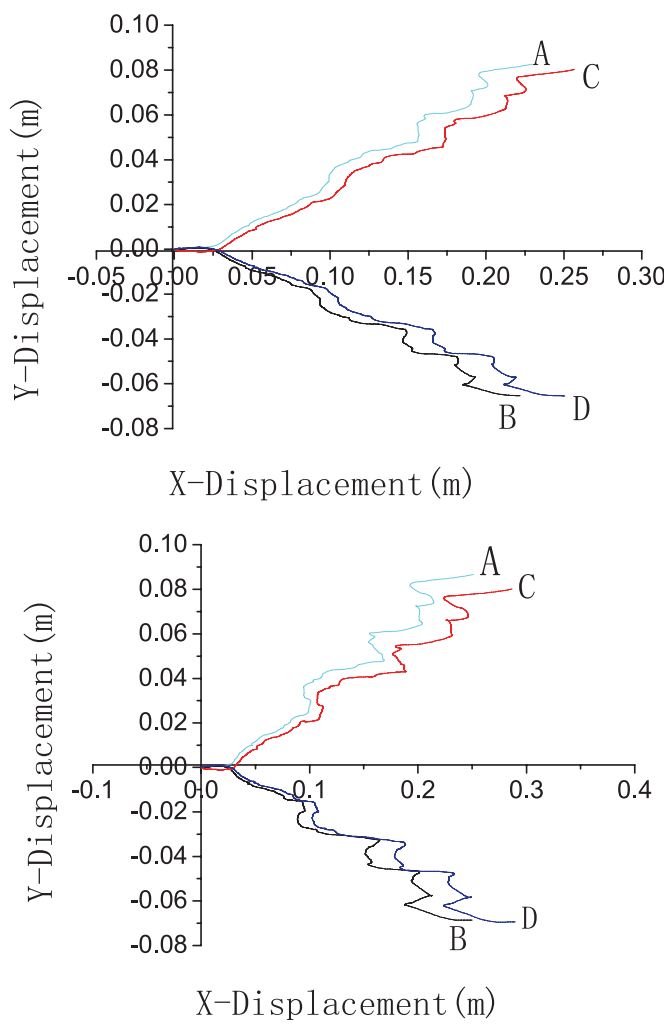

Fig 8:Different acceleration peak under A, B,C,D points of the horizontal and vertical deformation map

Through the analysis of numerical comparative: $0.1 \mathrm{~g}$ and $0.15 \mathrm{~g}$ displacement similar, so only indicate the horizontal and vertical deformation maps of $0.1 \mathrm{~g}$ and $0.2 \mathrm{~g}$ monitoring points. Figure 8 shows the horizontal and vertical directions at different portions earthquake deformation monitoring points, and FIG coordinate $\mathrm{Z}$ direction indicates the vertical direction of the deformation magnitude, $\mathrm{X}$ direction represents the magnitude of displacement in the horizontal direction. Breakwater structure inferred inclination of about 4 percent, according to "Port Engineering Seismic Design Guide" [11] judgment breakwater structural damage can be repaired, the liquefied layer of shallow, you can use vibration dense, compaction, cover weight and other measures.

\section{CONCLUSION}

This paper adopts FLAC3D finite difference software for a large reclamation project breakwater structure was simulated from the seismic design, structural foundation for the breakwater was dynamic process analysis, and analysis of the breakwater structure pore pressure ratio and under different earthquake changes in deformation draws the following conclusions:

1. Under the action of earthquake, the peak acceleration is $0.1 \mathrm{~g} .0 .15 \mathrm{~g}$ and $0.2 \mathrm{~g}$. the sand layer foundation breakwater structure will liquefaction occur, along with the increase of earthquake, liquefaction of sand layer area increases, the liquefied area mainly in the upper right side of the structure, liquefied depth by former deep, designed to focus on preventive measures considered;

2. Under the action of earthquake, the peak acceleration is $0.1 \mathrm{~g} .0 .15 \mathrm{~g}$ and $0.2 \mathrm{~g}$. For excess pore pressure and the displacement of part of breakwater structure foundation unit for monitoring, summarized the law of displacement ratio and changes in pore pressure, found in excess pore pressure value close to 1 , the structure is relatively large displacement, overturning phenomenon occurs breakwater structure, namely large extent liquefaction.

3. According to the deformation of the foundation structure may determine the extent of damage to this end breakwater is not large, the inclination is about $4 \%$, can be used after repair, take the measures such as vibration compaction, dynamic compaction and heavy weight in the liquefaction area, which is a reference for other similar breakwater structures.

\section{REFERENCE}

1. LU Xiaobin, TAN Qingming, WANG Shuyun, etal. Saturated Sand Progress[J]. Advances in Mechanics. 2004,34(1):87-100.(in Chinese)

2. SEEDHB, BOOKERR. Stabilization of potentially liquefied sand deposits using gravel drains [J].Journal of Geotechnical Engineering Div JCED,1976,102(07):1-15.

3. FANG Yun, TOWHATAI, GHALANDARZADEHA, et al. Mechanism of deformation and failure of gravitytype quay walls under earthquake liquefaction[J]. Earth Science-Journal of China University of 
Geosciences,2001,26(4):415-418.(in Chinese)

4. MA SHUO,LUO QI. Japan's Kobe earthquake damage harbor pier river embankment and Lessons[J]. Disaster, 1998,13(4):47-50(in Chinese)

5. WANG Liyan, JIANG Pengpeng, LIU Hanlong. Sandy foundation breakwater seismic residual deformation mechanism and liquefaction prediction method[J].Chinese Journal of Rock and Soil Mechanics,2010,31(11).3556-3562. (in Chinese)

6. JTS146 - 2012, Code of earthquake resistant design for water transport engineering[S].(in Chinese)

7. HAN SHI,GONG Jinxin, ZHANG Yanqing. Gravity pier foundation under earthquake liquefaction and deformation[J].Hydro-science and Engineering. 2013,8,(4):45-54. (in Chinese)

8. CHEN Yumin, XU Dingping. FLAC/FLAC3D Foundation and project examples[M].Peking: China Water Power Press,2008.

9. BYRNEPM, PARKSS. Seismic liquefaction: centrifuge and numerical modeling[J].Third International Symposium on FLAC and FLAC3D Numerical Modeling in Geomechanics, Ontario:2003.

10. GB50011 - 2010, Seismic Design of Buildings [S].(GB500112010, Code for seismic design of buildings[S]. (in Chinese)

11. International Navigation Association Seismic design guide lines for port structures[M].Nether- lands Balkema Publishers,2001.

12. Zhao jie,wang gui xuan,zheng yang,A nuclear power plant water diversion dam dynamic response and stability analysis[J].Journal of Disaster Prevention and Mitigation Engineering,2013,33(4):412-417.

13. LIU Hanlong, IAI S, ICHII K. Seismic response analysis of large-size caisson quay wall [J].Chinese Journal of Geotechnical Engineering, 1998, 20(2) : 26-30.( in Chinese)

14. Xu Zhiying,Shen Zhujing,Two-dimensional dynamic analysis method of seismic liquefaction effective stress[J].Journal of Hohai University(Natural Science Edition),1981,(3):1-14.

15. Ren Jieming,Su Jingyu,Dou Yuanming, Neural network Sand Liquefaction[J], Hebei University of Technology,2002,31(2):23-25.

16. Ishihara K.Undrained deformation and liquefaction of sand under cyclic stress[J].Soils and Foundation,1975,15(1):29-44.
17. McLaren, P. Sediment Trend Analysis (STA (R)): Kinematic vs. Dynamic Modeling[J]. Journal of Coastal Research, 2014,30(3): 429-437.

18. Han, ZQ; Wang, CY; Zhu, HY. Research on deep joints and lode extension based on digital borehole camera technology[J]. Polish Maritime Research, 2015,22(1): 10-14.

\section{CONTACT WITH THE AUTHOR}

Jie Zhao

Civil Engineering Technology Research and Development Center

Dalian University

Dalian, 116622

CHINA 